\title{
Paroxysmal cold hemoglobinuria
}

INSERM

\section{Source}

INSERM. (1999). Orphanet: an online rare disease and orphan drug data base.

Paroxysmal cold hemoglobinuria. ORPHA:90035

Paroxysmal cold hemoglobinuria $(\mathrm{PCH})$ is a very rare subtype of autoimmune hemolytic anemia (AIHA, see this term), caused by the presence of cold-reacting autoantibodies in the blood and characterized by the sudden presence of hemog lobinuria, typically after exposure to cold temperatures. 